\title{
Some new Late Proto-Yukaghir reconstructions with added thoughts and considerations on various etymologies
}

\author{
Peter Sauli Piispanen, Department of Slavic and Baltic Languages, Finnish, German and Dutch, Stockholm University;
} peter.piispanen@finska.su.se

In this paper, historical documentation of the Yukaghir languages spoken in the far northeastern Siberia are employed for the reconstruction of a small number of additional or revised Late Proto-Yukaghir (PY) roots. Late Proto-Yukaghir is the latest common ancestor of all varieties of Yukaghir, including the still spoken Tundra Yukaghir and Kolyma Yukaghir languages. Previously, numerous Late Proto-Yukaghir roots have convincingly and exhaustively been reconstructed in Nikolaeva's A Historical Dictionary of Yukaghir, published in 2006, and this meager report adds to those materials. The materials are presented and discussed in phonological and semantic terms, employing phonological methods similar to those of Nikolaeva's research, and adding semantic considerations missing from the dictionary.

The newly reconstructed or revised Late Proto-Yukaghir roots include: 1) Late Proto-Yukaghir *kejwa- 'to be thin', 2) Late ProtoYukaghir *ač̃- * *ači- 'to carry', 3) Late Proto-Yukaghir *pujö 'warmth > some sort of warming clothing: fur, feathers, hair, beard', 4) Late Proto-Yukaghir *inć- 'today; now', and 5) Late Proto-Yukaghir *nulińčz 'crowd'.

Furthermore, numerous etymological comments, notes, discussions and clarifying details are presented for Yukaghir lexicon, ranging from the obscure historical records to the modern languages, clarifying a few matters, correcting some and adding further information of interest to others. Yukaghir roots (or words of later Russian or Ewenki origin) are discussed, and given concrete meanings, in-

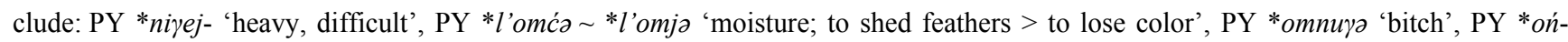
'crack, slit, opening', PY *per- 'threshold, dug in poles of a yurt door', PY *netl'ə 'fox', Rus. gavrik 'collar muffler, scarf', PY *šogi 'bag', PY *iwe:r 'place around the hearth', PY *eče: 'father', PY *mi:-bə 'cutter', PY *ejmə 'price, payment', Rus. piska 'penis', Rus. čaška 'cup', Rus. Varvara 'Barbara', Ewenki noyo:n 'green', and PY *nunkə 'sheefish'.

Keywords: Yukaghir, reconstruction, etymology, semantic change

\section{НОВЫЕ ПОЗДНЕПРАЮКАГИРСКИЕ РЕКОНСТРУКЦИИ И ДОБАВЛЕНИЯ К РАЗЛИЧНЫМ ЭТИМОЛОГИЯМ}

Пииспанен Петер Саули, Отделение славянских, балтийских, финского, немецкого и нидерландского языков Стокгольмского университета; peter.piispanen@finska.su.se

В статье на основе исторически засвидетельствованных юкагирских данных предлагается несколько новых или скорректированных реконструкций позднепраюкагирских корней. Позднепраюкагирский язык - это последний общий предок всех юкагирских идиомов, включая существующие ныне тундренный юкагирский и колымский юкагирский языки. Множество позднепраюкагирских корней было убедительно и исчерпывающе реконструировано ранее в словаре [Nikolaeva 2006], и данная статья - это скромная добавка к этому материалу. Представленные здесь данные обсуждаются с точки зрения фонологии и семантики с использованием фонологических методов, близких к методам И. А. Николаевой, и с добавлением некоторых семантических соображений, не учтенных в словаре.

Здесь представлены следующие позднепраюкагирские (ПЮ) этимологии: 1) ПЮ *kejwə- 'быть тонким', 2) ПЮ *ači- *ači'нести’, 3) ПЮ *риүӧ 'тепло > вид теплого покрытия: мех, перья, волосы, борода', 4) ПЮ *inć- 'сегодня; сейчас'; 5) ПЮ *nulińč 'толпа'.

Кроме того, приводится ряд этимологических комментариев, заметок, дискуссионных замечаний и новых деталей к юкагирским словам, от старых неясных записей до современных материалов, с пояснениями, исправлениями и новыми данными. Обсуждаются юкагирские корни (или поздние русские или эвенкийские заимствования), предлагаются новые

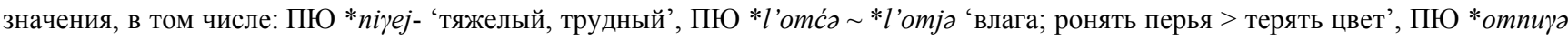
'сука', ПЮ *oń- 'трещина, щель, отверстие', ПЮ *per- 'порог, шесты, врытые в землю у входа в юрту', ПЮ *netl’a 'лиса', рус. гаврик 'шарф’, ПЮ *šogi ‘мешок’, ПЮ *iwe:r ‘место вокруг сердца', ПЮ *eče: 'отец’, ПЮ *mi:-bə ‘лезвие’, ПЮ *ejmə 'цена, плата', рус. писка 'пенис', рус. чашка, рус. Варвара, эвенк. поүо:n 'зеленый', ПЮ *nипкә 'нельма'.

Ключевые слова: юкагирский язык, реконструкция, этимология, семантический переход 


\section{Introduction}

Late Proto-Yukaghir (PY) roots, the common ancestral roots of all known varieties of the Yukaghir languages and dialects - spoken in the very far Northeast Siberia - were first reconstructed in Irina Nikolaeva's A Historical Dictionary of Yukaghir [Nikolaeva 2006]. A total of 2659 roots (or rather, word group entries) were exhaustively presented, a few hundred of which were also therein demonstrated to originate in borrowings from Russian, Ewen, Ewenki, Yakut and Chukchi. In fact, the previous reconstructions were so numerous and detailed that it is most difficult to add any more to these materials. Later research (mainly: [Piispanen 2013; 2015; 2016; 2018; 2019a; 2019b; 2020a; 2020b; 2020c; Nikolaev 2015]), however, has additionally uncovered many dozens of additional borrowings into Yukaghir (from the same donor languages as well as from the Yup'ik language branch of Eskimo, as well as from a hypothetical Northern Nivkh variety), actually invalidating many of the PY roots presented in the aforementioned dictionary. Only the prospective Eskimo and Northern Nivkh borrowings into Yukaghir could arguably be old enough to predate the PY stage of the language. In summary, the number of real demonstrable PY roots may actually be less than 2000 in total.

In this short work, I will present a few new PY root reconstructions (based on the very same principles as outlined in Nikolaeva's dictionary), correct a few of those older PY root reconstructions, and then summarize a lot of etymological thoughts and details of several different Yukaghir languages and dialects, clarifying many details. In this line of research, I have consulted numerous documents and books on documented Yukaghir lexicon of all varieties, including [Angere 1957; Atlasova 2007; Jokhelson 1898; Jokhelson 1900; 1926; Krejnovič 1958; 1982; Kurilov 1990; 2001; Maslova 2003; Nikolaeva, Shalugin 2002; Nyikolajeva 2000; Schiefner 1871a; 1871b; Spiridonov 1997; 2003], [Wrangel 1841] (reporting on Matjuškin), and more, and the results of this study are presented in this paper. ${ }^{1}$ Regarding transcription, I have remained completely faithful to the records, not changing the written letters even though it might have been warranted to reflect a known pattern of pronunciation or the modern language(s). In any case where the transcription has been changed for one reason or another this is clearly stated.

Nikolaeva states [Nikolaeva 2006: 9] that all aspectual suffixes are excluded from the reconstruction, even if they are attested in modern varieties. Only primary roots are reconstructed, and I will suggest that we both can and should do more than that; derived roots, complete with suffixes and aspectual markers, can be reconstructed as well (not only on the Late Proto-Yukaghir level, but also for even earlier chronological levels, which should be termed Middle Proto-Yukaghir and Early Proto-Yukaghir, respectively), which is what I have also attempted to do in this paper.

\section{On the regular phonology of Russian borrowings in Yakut and Yukaghir}

According to Yukaghir rules of prosody, and phonological stress, a root could only have root structures of the types: *(C)V:Cə- $\left(1^{\text {st }}\right.$ syllable stressed $), *(\mathrm{C}) \mathrm{VCV}-\left(2^{\text {nd }}\right.$ syllable stressed $)$, or $*(\mathrm{C}) \mathrm{VCC} \curvearrowright-$ These roots could then also be extended further into *(C)V:CəC(C)-, *(C)VCVC(C)-, or *(C)VCCəC(C)-, respectively.

\section{New or revised Late Proto-Yukaghir reconstructions}

Below I present a number of new or revised Late Proto-Yukaghir roots.

1. Late Proto-Yukaghir *kejwo- 'to be thin' > KJ keibe- 'to be thin', keibeje 'thin' $(<*$ kejwo-ja) [Angere 1957: 110]; KY kejbo- 'thin, high (of voice)'; KK kejbe-; KJ kejbe-; KL kejwej; B keivey, ME keivei, KY kejba-iril 'small intestine, lit. thin stomach', KK kejben-, kejbed'e- 'to make thin' [Nikolaeva 2006: 204]; TY kiiwije 'thin, frail part of smth; fontanel' (<*kejwo-ja), kiiwej-rukun 'smth frail and thin, lit. thin thing', (juon-)kiwijii 'top of the head' $(<*$ kejwo-jaj), kiiwe- 'to move (of a fontanel)' [Nikolaeva 2006: 214].

This Late Proto-Yukaghir root combines two different earlier reconstructed roots [Nikolaeva 2006: 204, 214]: PY *kejwo- \& *ki:wo-, respectively) into one, and adds additional Kolyma Yukaghir dialectal details to it. The root has undergone the change of $* j>i$ : only in the Tundra Yukaghir branch (a semi-regular feature according to [Nikolaeva 2006: 64]). Examples of this change include: KY pe:d'a pejd'a 'shoulder-blade; knot; elk'

${ }^{1}$ I wish to thank Mikhail Zhivlov, as well as two anonymous reviewers, for providing most rigorous and valuable comments and helpful insights on an early draft version of this paper. All remaining errors are of course my own. 
TY pi:d'e 'forelegs of animal' [Nikolaeva 2006: 349] \& KY kej- TY ki: — 'to give' [Nikolaeva 2006: 203]. That is, we also have the verbal root of PY *kejwa- 'to be thin' (> Kolyma Yukaghir forms) $>$ *ki:wo- (> Tundra Yukaghir forms). I suggest that this sound change is only effective in a stressed first syllable, as numerous Tundra Yukaghir words have the unchanged suffix ending of $-k e j$, and neither does it occur with the other plosive variant of -tej.

The root is also similarly nominally suffixed in both branches. Clearly, KJ keibeje and TY kiiwije really represent the same word, originating from one derivative of this PY root, namely *kejwo-je 'thin', a prosodically valid root of the form ${ }^{*} C V: C \partial-+$ suffix $*_{-j}$-. Secondary vowel lengthening is known in TY — and I conjecture that it could have arisen from contact with the Tungusic languages - but this is a matter for future study. This root originally had a stressed long $1^{\text {st }}$ syllable, which ${ }^{*}-e j$ - counts as: the long vowel ${ }^{*}-e j$ - is reflected as $-i i$ - in TY but remains as the diphthong -ei- in KJ. The ending -je $\left(<*_{-j}\right.$ o), then, is a nominal derivational suffix (missing from those listed in [Nikolaeva 2006: 79-83], but which nevertheless is real as it is found in at least twentysix Yukaghir nouns; [Piispanen 2020a: 153-156], while the change $*_{-} w->-b$ - is common in Kolyma Yukaghir. The TY word kiwijii 'top of the head' (*ki:wo-jo-j), appears to be suffixed yet once more, this time with $*_{-j}$, an assumed diminutive marker. Notably, Nikolaeva herself did correct the spelling of the old Billings (B in the above) and Schiefner documentation for this word [Nikolaeva 2006: 21], which is most agreeable.

An anonymous reviewer raises the valid question if this suffix can actually be considered a productive nominal suffix. In Yukaghir, there is also the derivation of 'verb > particle', which is productive. A criterion for morphological productive would be evidence that most particles can be converted into nouns, but there are far fewer examples of the substantivization 'particle $>$ noun'. Indeed, it is possible that $*_{\text {-jo }}$ represents a historical nominalizing suffix, and that it is now only found in fossilized form in a few dozens of words. ${ }^{2}$

Regarding the semantics, the original meaning of this root, as evidenced in both Tundra and Kolyma Yukaghir, appears to have been 'to be thin'. With secondary semantic development, and use of a diminutive marker, we have obtained TY kiiwije 'fontanel', that is the anatomical feature of the soft membranous sutures between the cranial bone that makes up the top part of an infant's skull. The fontanel is thus a very thin section of the upper cranium, even a gap in those new-born. TY juon-kiwijii is directly derived through these secondary semantics with a literal meaning of 'small fontanel of the head', which indeed is located exactly at the top of the head. For somewhat similar semantic ideas, cf. TY juond-ewče 'spear; top of the head, lit. point of the head'; KY jo:n-šomor 'top of the head; January, lit. top of the head' [Nikolaeva 2006: 190].

2. Late Proto-Yukaghir *ači- *ači- 'to carry' > TY ači(:)d-onoj 'мешочек для мелких мужских вещей = man's bag for carrying small things, lit. load sack' [Kurilov 2001: 55; Nikolaeva 2006: 95; Atlasova 2007: 14]; KY āč̄- 'vinni; cipelni = to take; to carry' [Nyikolajeva 2000: 129]; SD ačim 'притащила, затащила; потянула = she dragged; she pulled' [Spiridonov 2003: 8].

First off, it must again be pointed out that Nikolaeva's dictionary only reconstructs primary roots, with all aspectual suffixes having been excluded from the reconstructions. This is indeed a reasonable start, but I believe that we both could and should start reconstructing derived roots as well. Therefore, in this entry I will suggest no less than four different reconstructive derived roots: PY *ač̄ $\sim$ * $\boldsymbol{a} \breve{c} \boldsymbol{i}$ - 'to carry' (discussed here in detail because it is seemingly unrelated to the other following roots); PY *waj- 'to do; to build' (the basic underived root, but which may also directly function as a verb), and, actually, based on lexical evidence, the derived forms

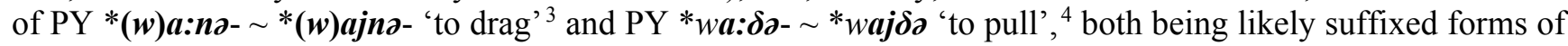
the basic root $*_{w a j}$ - followed by assimilation to $* \boldsymbol{w a}:-$. Future research is required to clarify and separate all details.

This Late Proto-Yukaghir form, *ačç- *ači, is reconstructed here as a separate root, in contrast to Nikolaeva [Nikolaeva 2006: 449] where it is connected to the underived PY root*wa:- $*^{*} \boldsymbol{w a j}-\sim *^{*} \boldsymbol{w e}:-\sim \boldsymbol{w}_{\boldsymbol{w}} \boldsymbol{j}-$, which has

${ }^{2}$ Which by itself does not pose any problems because according to the author's own statement the listing was never intended to be a complete list of all historical Yukaghir suffixes; a full one hundred and eighty-three inflectional and derivational suffixes were given, and there are more existing suffixes than those presented there. An anonymous reviewer further points out that the ending is $-j \partial /-d^{\prime} \partial /-c ̌ \partial$, a nominalized participle; this is an agreeable etymological origin for this marker which has since become (at least during some period of time if no longer), I will argue, a productive deverbal nominal derivational suffix (suggested in [Piispanen 2020a: 322-325]).

${ }^{3} \mathrm{Cf}$. KY a:nə- 'to pull, to drag (a sledge, a boat)'; KK a:ne-; KJ a:ne-; KD a:ne-; M anai, KY a:ńajo:- 'harnessed (of a dog, a reindeer)'; KJ a:ńńejo-, a:nejo-; M ańeboi, ańeboni, ańelwonpa (Nikolaeva, I. 2006: 449).

${ }^{4} \mathrm{Cf}$. KY $a: d$ - ' to pull'; KK $a: d e-; \mathrm{KJ}$ a:de-; KD a:de-; TY waarej-; TK wa:rej-; TJ worei-, wa:rei- '+ to take out, to extract'; TD warei-, uarai-, uwarai-, wo:rei-, uo:rei- '+ to take out' [Nikolaeva 2006: 449]. 
a basic meaning of 'to do; to make; to build'; this root should probably only be reconstructed as *waj-, because assimilation may produce *wa:- and palatalization may produce ${ }^{*} \boldsymbol{w e j -} \boldsymbol{>}^{*} \boldsymbol{w e}$ :-. I do not believe that $\boldsymbol{w}_{\boldsymbol{w}} \boldsymbol{j}$ - is to be connected to *ači- * *ači due both to semantic and phonological differences. It would seem as if the difficulties in reconstructing one single root have arisen from the inclusion of words belonging to at least three, possibly four, different roots, reconstructible already at the Late Proto-Yukaghir level, as suggested by the various meanings. I would suggest that these three nearly identical roots had the meanings of 'to do; to make; to build', 'to pull' (likely related to 'to drag') and 'to carry', as outlined above. The phonological details are somewhat difficult to sort out, but not impossibly so. In any case, we may reconstruct PY *ačč- $\sim$ *ači- 'to carry' as based in evidence both in the Tundra and Kolyma Yukaghir branches of languages (details follow), possibly, and even probably with the long second vowel.

Previously, a Tundra Yukaghir compound meaning a 'man's bag', ači(:)d-oyoj ( $<*$ ač̄-nt-oyoj) had a nonetymologized first part, and this part was otherwise not attested anywhere else. However, the missing piece of required information to etymologize it is found elsewhere with the KY verb $\bar{a} \bar{c} \bar{l}$ - 'to take; to carry' [Nyikolajeva 2000: 129], another non-etymologized Yukaghir root, and likely also with fragments of the Kolyma Yukaghir dialect documented by Spiridonov with SD ačim 'he dragged, he pulled' ([Nikolaeva 2006: 449] has SD aci- 'to bind, to tie together', but that should be a separate root). Nikolaeva appears to have missed some of these comparisons when later compiling A Historical Dictionary of Yukaghir [Nikolaeva 2006]. In the TY compound, the second part, oyoj, simply means 'bag, sack' [Nikolaeva 2006: 329], which originates in the root oy- 'to put on'. The full compound, connected through the genitive marker *-nt-, thus literally means 'load sack', a load sack (also called a bulk bag) simply being an utility in which to carry or transport lighter materials something akin to a satchel, messenger bag or carriel. In KY, the root instead represents a verb and has undergone a small semantic shift of 'to load' > 'to carry, to take', but the connection is still transparent, just as it is with the TY compound. There is a semantic parallel of formation to be found with TY čiid-onoj 'pocket', etc. [Nikolaeva 2006: 131], although in this case the first part of the compound is not clear to me.

Other important comparisons are to KY a:či: — 'to pull; to draw (a bow)'; KK a:t'i-, at'i-, a:si-; SD aci- 'to bind, to tie together', TK wajči- 'to take out'; TD uaiči-, waiči- [Nikolaeva 2006: 449], which have previously been connected to underived PY root ${ }^{*} w a-,{ }^{*} w a j-,{ }^{*} w e-,{ }^{*} w e j-($ the long-voweled forms are clearly assimilations of the forms containing the $*_{-j}-$ ). Again, we note that the entry appears to mix representatives of several different similar roots and meanings. These aforementioned words, however, may not necessarily be directly connected to the words presented in the entry of this paper, and could be natural derivations of *waj- 'to do; to make'. Therefore, the long vowel of the words in this paragraph does not automatically mean that the vowel of the root reconstructed here must be long as well.

As to the reconstruction, some forms suggest an underlying Late Proto-Yukaghir root of *ač̄i- 'to carry', which is herewith reconstructed, although the long vowels of some Yukaghir forms could be the result of secondary vowel lengthening as formed from an original short-voweled PY root of *ači-, which then would have been a prosodically valid root of the type $*(C) \mathrm{VCV}$ - (where the second syllable is stressed). Thus, the vowel length of the PY form is unclear; if the long vowel form is primary, however, it could suggest that the root is actually a borrowing. Further, an anonymous reviewer wisely points out that the genitive marker $-d$ - of $a c i_{i}-d$-onoj is unclear because the genitive does not usually combine with uninflected verbal stems. The marker could follow a particle, such as in a possible *a:či:-ja-d-oyoj, but such a form is non-attested.

In that vein, I originally believed the Yukaghir root a possible Mongolic borrowing, cf. Proto-Mongolic *ači- 'to load; to carry on one's back' [EDAL 519]; *ači- (<*arči-) 'to load' [Nugteren 2001: 264] > Written Mongolian $a c ̌ i-$ 'to load a vehicle or animal; to burden, to put on back; to pile up; to accumulate; to throw one's opponent in wrestling over one's back and thigh', ačigči 'loader', ačija(n) 'load, burden, freight, cargo', ačijala'to load, to burden' [Lessing 1960: 8]; Middle Mongolian ači- 'to load' [Haenisch 1939; Kozin 1941; Aptullah 1934]. However, that does not seem possible because there are no attested forms in the needed intermediary transmitting languages of Yakut, Ewen or Ewenki, and, furthermore, assuming borrowing bears no advantages to instead assuming an internal Yukaghir etymology for the root discussed here. The Mongolic root is actually borrowed as (Urulga) Ewenki atiga 'satchel, riding sack', (Kumare) Ewenki atiyalan 'to load' and Manchu ačika 'burden; saddlebag' [Poppe 1966: 192; Doerfer 1985: 100; Doerfer 2004: 99; Rozycki 1994: 11]. I note that perhaps Yakut atyjax 'берестяное лукошко = birch basket' [JRS 52], which describes another type of 'load bag' should also be included in those comparisons, but none of these forms have the required phonological shape for providing the Yukaghir root. An anonymous reviewer helpfully suggested that this Yukaghir root be related to KY a:- TY wa:- 'to pull, to drag, to carry' with -či:- being a common iterative suffix; indeed, a relation between $*(w) a-c ̌ i$ :- and $*(w) a->*(w) a$ :- is of course perfectly regular from a phonological point of view, but any original ${ }^{*} w$ - would have been lost in Kolyma Yukaghir, but retained in Tundra Yukaghir. This 
certainly is a possible internal etymological origin for the Yukaghir root handled here, but it is not necessarily so. Rather, because we have an attested Tundra Yukaghir ačil:()d-oyoj we can tell from this that the original form was actually *a-či(:)-, not *wa-či(:)-, and so the differentiation of analysis into several separate Late Proto-Yukaghir roots is warranted.

Rather, I believe that this root *a-či(:)- is distinct from the *waj- 'to do; to make' already reconstructed by Nikolaeva (with her *wej-, I suggest, merely being a phantom reconstruction based on later palatalized words, and which may be scrapped altogether). In summary then, the similar roots, meaning slightly different things, have different derivational patterns, but some could also represent different, non-related roots altogether, making both the semantic and phonological analyzes difficult, and to be sorted out by future research.

3. Late Proto-Yukaghir * puy $\ddot{\boldsymbol{o}}$ 'warmth > some sort of warming clothing: fur, feathers, hair, beard' > KY puge- 'hot', pugö 'summer', pugelbe: 'fur; hair; feathers', puged's 'sweat'; TY pugej- 'hot', pugude 'heat, warmth', puguče 'fur; hair; feathers'; MU bugö'ntscha bugötsch 'hot; sun', bugü'bee 'beard, moustache'; KD nie-pugare-, KJ ńe-pugorei-, ńe-puged'ia- 'reconciled with, lit. mutual warmth', etc. with numerous derivatives in all Yukaghir languages and dialects.

Three separate homonymous roots were previously reconstructed as Late Proto-Yukaghir * puy $\ddot{\boldsymbol{o}}$, one with meanings related to 'summer', 'warmth' [Nikolaeva 2006: 366], and the other with meanings related to 'fur', 'feathers', 'hair' [Nikolaeva 2006: 366-367], and the third with the meaning of 'reconciled with' [Nikolaeva 2006: 367]. However, it should be clear from both the semantics and the phonology that all of the words of all three entries, in various suffixed forms, can be described by one single PY root only, namely *puj $\ddot{\boldsymbol{o}}$ 'warmth > some sort of warming clothing: fur, feathers, etc.'.

The meaning of 'reconciled with' is a literal, later Kolyma Yukaghir derivative meaning 'mutual warmth', a fact having avoided previous research; $n$ e- is a well-attested reciprocal marker [Nikolaeva 2006: 292 -293]. It is both a metaphorical and literal interpretation for to have warmth mutually for each other is to be in agreement, or, indeed, to reconcile. Also, since sharing beds in the cold nights - both between family members, friends and visitors - was the custom for probably hundreds of years in Yukaghir lands [Jokhelson 1926: 6268], this could only happen if both parties agreed to such an intimate act and if they were on relatively good terms with each other, i.e. they were to literally share mutual warmth in the night. The ending -rei- $\left(<\mathrm{PY} *_{-}\right.$raj) is a perfective transitive marker [Nikolaeva 2006: 83], which renders the literal meaning into 'to have been reconciled with', i.e. a completed action.

This semantic development has a parallel with words for 'clothing' in the Samoyedic languages, developed from an original Proto-Samoyed root meaning 'warmth': Proto-Uralic *lämpi 'warmth, warm' > Proto-

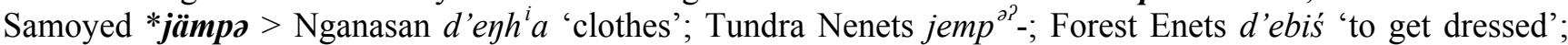
Taz Selkup čęmpit- 'gird'; Kamassian d'èm- 'warm (TR)' \& Finnish lämpö 'warmth', lämmin, lämpimä'warm'; Erzya Mordvin l'embe, Moksha Mordvin l'ämbä 'warmth'; East Mari lewe 'warm', etc. [Aikio 2014: 83-84].

Lastly, Nikolaeva hesitantly suggested that the root denoted to 'warmth' may be a borrowing from ProtoTungusic *peku- 'hot' [EDAL 1084], but given the differences in vowels, the extremely extensive spread in Yukaghir and the secondary semantic developments, this seems unlikely to be so.

4. Late Proto-Yukaghir *inć- 'today; now' > KY id'i: 'here; now' [Nikolaeva, Shalugin 2002: 19; Maslova 2003: 545]; KK id'i-, KJ id'i; KD id'i- TY id'ie(nen); TK id'ie-, SU id'e-; M ide; MC ine, idet 'today' [Wrangel 1841: 123]; B indzhi 'today'; ME intschi; TY id'ire(ney) 'now'; TK id'iere 'today'; TD id'ire; MU indschida 'today'; KD id'il'e, id'itiy 'present day'; id'ilgene 'up to now', TY id'iretey 'from now on'; id'ieie 'modern', TK id'iene 'now'.

Late Proto-Yukaghir *inćígo- 'morning' > MO endego 'today'; TY id'igojgi- 'morning'; TK id'igojge, id'igojege-, id'igöjgir.

Through analyses of historical records, two roots denoting time can be reconstructed. Nikolaeva [2006: 174] reconstructed a short root *inć- and therein many words meaning 'now; today' are included as well as others. It is clearly also possible to reconstruct *incíigo 'morning', specifically, which I give above, based on the same data. In the above, I have separated all such words into the respective grouping. Furthermore, there are also MO endte 'yesterday', iendti 'tomorrow', but their phonological structure and derivational patterns are unclear. As to the ending - $\boldsymbol{\gamma} \boldsymbol{o}$, which Nikolaeva [Nikolaeva 2006: 175] technically suggests points at *inći- $\gamma-/ *^{*}$ inći- $\eta k$-, we are unable to fully analyze it, just as an anonymous reviewer points out. We could, however, be dealing with a locative case here (cf. TY - $\gamma \partial$, KY -gə, a locative affix; [Nikolaeva 2006: 80]), which could make sense in forming this temporal aspect. 
5. Late Proto-Yukaghir *nulińčo 'crowd' > TK nulid'e 'pack (of wolves)'; TY nulid'e 'стая (волков) = pack (of wolves)' [Kurilov 2001: 293; Atlasova 2007: 39], nulid'e-göde 'толпа, скопище, банда = crowd, gathering, gang, lit. crowd of man' [Kurilov 2001: 293; Nikolaeva 2006: 313]; KY nuled'e 'crowd' [Maslova 2003: 550].

This PY root was first reconstructed elsewhere using Tundra Yukaghir representatives only [Nikolaeva 2006: 313], but hitherto unnoticed Kolyma Yukaghir representatives can be added here as well, which demonstrates that this is a secure PY reconstruction with *nulińčo- 'crowd', albeit the KY form instead suggests PY *nuleńčo-. We could almost expect palatalization of the lateral in the former reconstruction if it is correct, although this is not necessary. The latter reconstruction could be faulty if we assume regressive vowel assimilation in the KY form, which actually seems fairly likely. Therefore, Nikolaeva's original reconstruction still seems the most likely. Clearly, this word could be used for crowds of people, wolves, and likely reindeer and possibly also flocks of birds. ${ }^{5}$

\section{Some etymological notes and corrections}

By comparing various Late Proto-Yukaghir (PY) roots and its subsequent cognates with homonymous Yukaghir roots presented in other non-referenced works (in this case for example: [Maslova 2003]), the semantics can be expanded upon and the meanings of said PY root be clarified. It should be noted that in Nikolaeva's dictionary no PY root is ever given a direct meaning, although the original meaning is most often fairly clear from the various derived Yukaghir forms; the method of presenting only the shortest root possible, however, has the problem of some words, which start out phonologically similar, but which otherwise do not belong together etymologically, are lumped together into the entry. In this work, I therefore attempt to actually give each PY form an actual meaning. My reasoning is that we should be as accurate as possible regarding the semantics of all documented words. This is important not only for the purposes of etymology, but also for being able to carry out long-range comparative studies. ${ }^{6}$ Surely we are obliged to point out any shortcomings or discrepancy in available data. For this very reason, I have opted to present some corrections to older documentation as well as to make some other clarifying notes of interest, which, granted, is a subjective criteria, in this section.

The Late Proto-Yukaghir root *nizej- has been reconstructed [Nikolaeva 2006: 299] and the various Kolyma Yukaghir forms therein all suggested the meaning of 'heavy'; cf. KY nigejo: 'heavy'. However, unnoticed thus far, another meaning can also be ascribed to this root with the homonym KY nigejo:j 'difficult; have difficulty' [Maslova 2003: 549]. As 'heavy' and 'difficult' are semantically connected also in many other languages we can safely assign the double meaning of 'heavy; difficult' to this PY root. While what counts as a distinct meaning is naturally a separate semantic and lexicographic issue, the difference in figurative meaning is still worth to point out because this distinction is not made in every language.

The Late Proto-Yukaghir root *l'omćo *l'omja has been reconstructed [Nikolaeva 2006: 248] with meanings connected to 'moisture' and 'to shed feathers'; cf. KY l'omd'a 'moisture; to shed hair, feathers'. While the connection between these two separate meanings is not at all clear, another attested meaning of this root can be given with the non-noticed KY l'omd'aj 'fade, to lose color' [Maslova 2003: 548], which is what happens when a bird, for example, in winter time sheds its feathers. Thus, this PY root can be assigned the double meanings of 'moisture; to shed feathers > to lose color'. Without being able to demonstrate it, I suspect that the meaning of 'moisture' in Yukaghir has arisen from a semantic borrowing from a neighboring language with a phonologically close form with that meaning.

The Late Proto-Yukaghir reconstruction of *omnuy 'bitch' > RS omnúga 'bitch'; ME omnuga [Nikolaeva 2006: 327] can be additionally connected to KY omnuga 'shame', which was previously placed in error with PY *omol-, which means 'shame' [Nikolaeva 2006: 328]. While these two roots may be semantically and phonol-

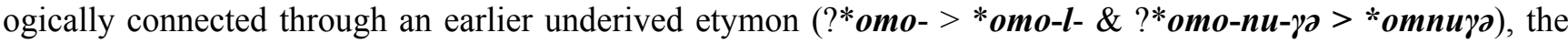

\footnotetext{
${ }^{5}$ Perhaps there were also unattested TY compounds such as nulid'e-nada 'flock of birds' and nulid'e-talaw 'groups of wild reindeer'. It can be assumed that a native Yukaghir speaker could conclude the meaning of these compounds even if they had not heard them before.

${ }^{6}$ Consider Finnish koti 'home', which originates in *kota 'hut', and talo 'house', which originates in *taloi 'house', seemingly from (*talas 'platform, boathouse' $<$ ) *tala 'shelter, storage house'. We could not follow the semantic development if it were not for the meanings documented in related languages. Thus, accurate semantics and documentation is of utmost importance.
} 
KY word above should be connected directly to the former root only. There actually is a PY *omo- from where words meaning 'good, correct', 'to cure', 'to love' are derived, and it is easy to see how these, in corrupted form, could denote 'bitch' and 'shame'. This can be semantically compared to: Proto-Indo-European *keh $\boldsymbol{h}_{2} \boldsymbol{r o s}$ 'loved' (<* $\boldsymbol{k}^{\boldsymbol{e} \boldsymbol{h}_{2^{-}}}$'to wish; desire'), continuing on in Proto-Germanic ${ }^{*} \boldsymbol{h} \overline{\boldsymbol{o}} \boldsymbol{r} \overline{\boldsymbol{g}}$ 'whore' \& modern English 'whore', where the original meaning of 'to love' has been corrupted into 'whore', a vulgar, derogatory word, and the same thing has seemingly happened in Yukaghir with 'to love' > 'bitch'. We thus have two derivatives already on the proto-language level: PY *omol- 'shame; to be shameful' \& PY *omnuy 'bitch', both possibly connected to PY *omo- 'good, correct; to cure; to love', which in itself might be related to Proto-Finno-Permic *oma 'proper; property' [UEW 717].

A Late Proto-Yukaghir form of *oń- was reconstructed to cover various Tundra Yukaghir words for 'crack' and 'opening'; cf. TY onil 'crack' [Nikolaeva 2006: 328]. I believe a Kolyma Yukaghir representative can be added to those cognates with KY onil 'crack, slit' [Maslova 2003: 551], making this a secure PY reconstruction. As an anonymous reviewer suggested, the correspondence of $\eta<>n$ is plausible when considered a palatalization of the engma when followed by an -i- (i.e. $\eta i->n i-$ ) just as occurs, for instance, in Nenets. An extreme phonological parallel in Yukaghir is found with $-\eta->-n-,-\dot{n}-,-\check{c}-,-g-,-n g-:$ PY *möyör > TY möner 'thunder, noise'; TD moner mońor; RS mučer; B mungzscha; KY mugerpo- 'to buzz, to drone' [Nikolaeva 2006: 275276], although the development of at least of these forms can be ascribed to the expressive nature of this root (or onomatopoetic character as Nikolaeva calls it in the entry), and other clear examples are difficult to find. ${ }^{7}$ An alternative PY reconstruction for the root discussed here could thus be *oy-. Now, because oy- is, phonologically speaking, a small step from ay- (exemplified by: Ewenki aya 'wild game; beast', borrowed as SU onyl, B onye, ME ongei 'reindeer' [Piispanen, P.S. 2015: 244-245], ultimately, all of these words for 'crack' could ultimately have arisen from PY *aba, from where words for 'mouth; opening' are derived, and which is likely related to Proto-Uralic *aye 'mouth; opening', aya- 'to open' [UEW 11-12]. These roots could be part of a Wanderwort, as similar forms are found in numerous Northeastern Siberian languages.

The Kolyma Yukaghir word perul 'part of the poles forming the door in a yurt that is dug into the ground' (< PY *per-; [Nikolaeva 2006: 350]) is perfectly synonymous with KY perul 'threshold' [Maslova 2003: 552]. The bare root obviously also means 'threshold'.

The original Yukaghir word for 'fox' appears to have been Late Proto-Yukaghir *'netl'a 'fox' (entry 298 in [Nikolaeva 2006: 298]). To those mentioned in that entry (KJ ńatle 'fox; wolverine (Gulo gulo)'; KD ńetle; TY nitle, ńetle; TK netle; TJ ńetle; TD nietle; TK netli- 'to hunt a fox'), another representative can be added with RS ńaoe-netla 'a kind of fox' (segmented as RS ńaoen-etla elsewhere), given its own entry 1373 on page 289. The old records are fairly often lacking in phonological accuracy and detail, but there should be no doubt that this RS word belongs among the others for 'fox'. The first part of the compound, ńaoe-, is not at first clear at all but should describe what type of fox we are dealing with here (perhaps a color). Here, a reviewer very helpfully suggested that the word might actually represent the cognate of TY na:wo- 'white'. In highest likelihood, this interpretation is correct because ńaoe-netla (<*'ńa:wo-ńetl'a) would literally mean 'white fox', a very apt description of a 'polar fox'. Another word in RS, ńandimide 'black and grey fox' (also given in entry 1373 on page 289) must be considered separate from this other RS word, and it cannot be related to the general Yukaghir word for 'fox' either on phonological grounds, thus leaving the latter completely non-etymologized.

Nikolaeva correctly notes in her historical dictionary (likely basing the assumption on phonology) that dialectal Russian gavrik has been borrowed into Tundra Yukaghir [Nikolaeva 2006: 167], and indeed the word is documented in TY as kawsik, kausik or gawsik (TK kawcik in older documentation) 'collar muffler, scarf made of the fur of a young reindeer or of a reindeer killed in early autumn'. In addition, I note that this word is also found in verbal form with TY gavrikne- 'to have a gavrik' [Kurilov 2001: 79], which I believe is worth mentioning not only because it shows the depth of nativization into Yukaghir of this borrowing, but it also demonstrates that the suffix -ńe-(-ńz-) is very productive. As an anonymous reviewer points out, this effectively combines the Russian words in code-mixing situations.

Furthermore, SD šogi 'bag' [Spiridonov 2003: 27; Angere 1957: 228] is likely connected to KD xancogi 'leather bag'; the sibilant in SD contra the affricate in KD, which both describe Kolyma Yukaghir dialects, can be explained - during the $19^{\text {th }}$ century, male speakers of Kolyma Yukaghir pronounced both the phonemes

${ }^{7}$ As an anonymous reviewer correctly points out, in some documented cases $n$ and $\eta$ are simply confused in their transcription because $\eta$ is absent in Russian. 
$\check{c}$ and $\check{s}$ as the phoneme $\check{c}$, while female speakers of the same always distinguished between the two phonemes [Jokhelson 1898: 153-154]. This leads to the logical conclusion that earlier speakers, in contrast to modern speakers, must have rendered an $*_{\breve{s}}$ in this word as the affricate $* \check{c}$, and that word must therefore have been * šogi 'bag'. Jokhelson himself believed that the Yukaghir word was etymologically derived as a translation from old Russian meshok 'bag' [Jokhelson 1926: 39], but such a front-truncated form would be most unusual and it does not look very convincing. The first part of xan-cogi is not known from anywhere else in Yukaghir lexicon in this form, and must therefore phonologically go back to *qan- (i.e. *qan-šogi, or *qa-n-šogi if ${ }^{*}-n$ constitutes the genitive marker of a compound). The KD form was hesitantly suggested to originate from *qansə- but the analysis presented here shows that this cannot be correctly segmented. The KD form can instead be compared to KY qa: $d$-o: 'leather trousers with fur inside' $(<* q a n t-o:)<\mathrm{KY} o$ : 'trousers', which may exhibit a hypothetical * $q a(n)$ - 'leather' as well. Could there also be a connection to TY kuod'e 'leather belt for tying

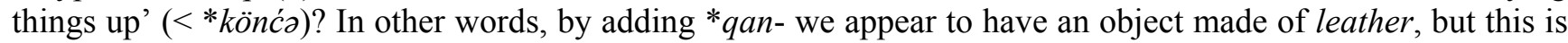
a poorly attested and unfounded hypothesis and is to be considered most tentative only.

The TY word ibier 'place around the hearth' [Atlasova 2007: 17] can be etymologized through Late ProtoYukaghir *iwe:r [Nikolaeva 2006: 179], which already had representatives in Kolyma Yukaghir and several other dialects, but not TY per se. While a reader of Atlasova could possibly make the connection himself/herself, it is still worth to point out that with the TY addition this PY reconstruction is further attested and therewith suggesting its correctness.

The Late Proto-Yukaghir root *eče: 'father' [Nikolaeva 2006: 150] (> KY ě̌e: 'father') — which has Uralic cognates - can also be given a modern TY cognate with öčid'ie 'uncle' [Atlasova 2007: 44]; cf. TK oqt'idie (sic?) 'father's younger brother', TJ očidie 'father's younger brother, father's younger male cousin'.

An etymological clarification can be given. Nikolaeva noted for the MU word míwe 'knife' [Nikolaeva 2006: 270] that it might be related to Proto-Tungusic * mi: - 'to cut' [TMS 535]. Indeed, it should be a borrowing, with a seeming nominal derivational suffix $-w \partial$ attached to the borrowed verbal root. Nikolaeva suggests exactly this same suffix with another borrowing [Nikolaeva 2006: 206], namely Proto-Tungusic *kende'threshold; to hinder, to obstruct' [EDAL 663-664], borrowed as: KY kenbə 'fence', etc. (<*keniwo). In Yukaghir, PY *-wo is normally considered an intransitive verbal marker [Nikolaeva 2006: 83], but the same could tentatively be listed as a nominal derivational suffix. However, as pointed out by an anonymous reviewer, a better assumption for the development of the words above, instead of creating additional ad hoc suffixes, is to instead use the known nominal suffix -bə/-bul [Nikolaeva 2006: 79], which typically derives nouns from verbs, and which could go back to *-mbo, but this is not fully clear. Using this, the MU word míwe 'knife' could have arisen from *mi:-bo 'cutter', instead of from *miwa. Likewise, KY kenbə could have arisen from *ken-bo $(?<*$ kendo-bo- $)$.

SD ajmagrehtajan 'платить, вносить, давать = to pay, to bring in, to give' [Spiridonov 2003: 7], describes a dialect of Kolyma Yukaghir. This verbal root clearly belongs to PY *ejma > KY ejma 'price, payment', SU eimatut $\sim$ eimegen $\sim$ eimege 'price, payment', TK \& KK ejmeš- 'to pay', etc. [Nikolaeva 2006: 154], in a set that previously was without an SD representative. The morphological structure of the SD root is not clear, but it no doubt describes a verbal form of 'price', just like the TK and KK roots above do with 'to pay'.

TD pička 'penis' [Jokhelson 1926: 326] can be added among the Yukaghir words of KY, KJ and SD [Nikolaeva 2006: 353] as also having a loanword etymology originating in Rus. piska. This adds a Tundra Yukaghir representative to these Kolyma Yukaghir words.

SD caska 'mug' was suggested borrowed from Rus. čaša 'чаша = bowl' [Nikolaeva 2006: 126], but rather, as is clear from the phonology, it is instead a borrowing from Rus. čaška 'чашка = cup'. While both Russian words should have the same etymological origin, these matters must be made clear. The latter word has also been the source of numerous borrowings into Yukaghir [Nikolaeva 2006: 126 - 127], and it was just a minor misstep to connect the SD word in error to the former Russian word instead of to the latter.

A female name recorded only in TY folklore, warwaa, was reconstructed as a PY root (in [Nikolaeva 2006: 454]), but this must surely just reflect a contracted form of the Russian female name Varvara — as suggested to me by Mikhail Zhivlov - which is the Russian equivalent of English Barbara. No PY root needs to be reconstructed for this borrowed name. 
Previously, KY ńoyo: - 'green, blue' has hesitantly been suggested a Tungusic borrowing [Nikolaeva 2006: 308], cf. Proto-Tungusic *l'og- 'green, dark' [EDAL 875]. Principally, this is correct, but as the EDAL does point out the TMS entries for the corresponding Tungusic forms, from where the data is collected, are confused and intermingled with some Mongolic borrowings, and greater accuracy and detail can be given. Specifically, the KY form is directly borrowed from Ewenki noyo:n 'green' ([TMS 601; Vasilevič 1958: 297] — the word is missing altogether from Ewen); this explains the vocalism, and sporadic changes between $\eta$ and $\gamma$ do occur in Yukaghir. The final $-n$ has upon borrowing been reinterpreted as the common Yukaghir genitive marker $-n$ and was therefore scrapped with the borrowing. The Ewenki word itself was borrowed (as suggested in the TMS) from Mongolic, cf. Written Mongolian noguran [Lessing 1960: 588].

So far, TD nogiey 'kind of salmon found in a lake' (entry 1482 in [Nikolaeva 2006: 305]) has remained wholly non-etymologized and without comparison. There is, however, also TY nunge( $\eta)$ 'нельма = nelma, a species of salmon' [Kurilov 2001: 293], which describes the same word, and which was given as derived from PY *nunka 'sheefish (Stenodus leucichthys)' (entry 1550 on page 315), and the TD form belongs in the latter entry, meaning that entry 1482 can be deleted altogether. The sheefish is more commonly called nelma salmon in Siberia.

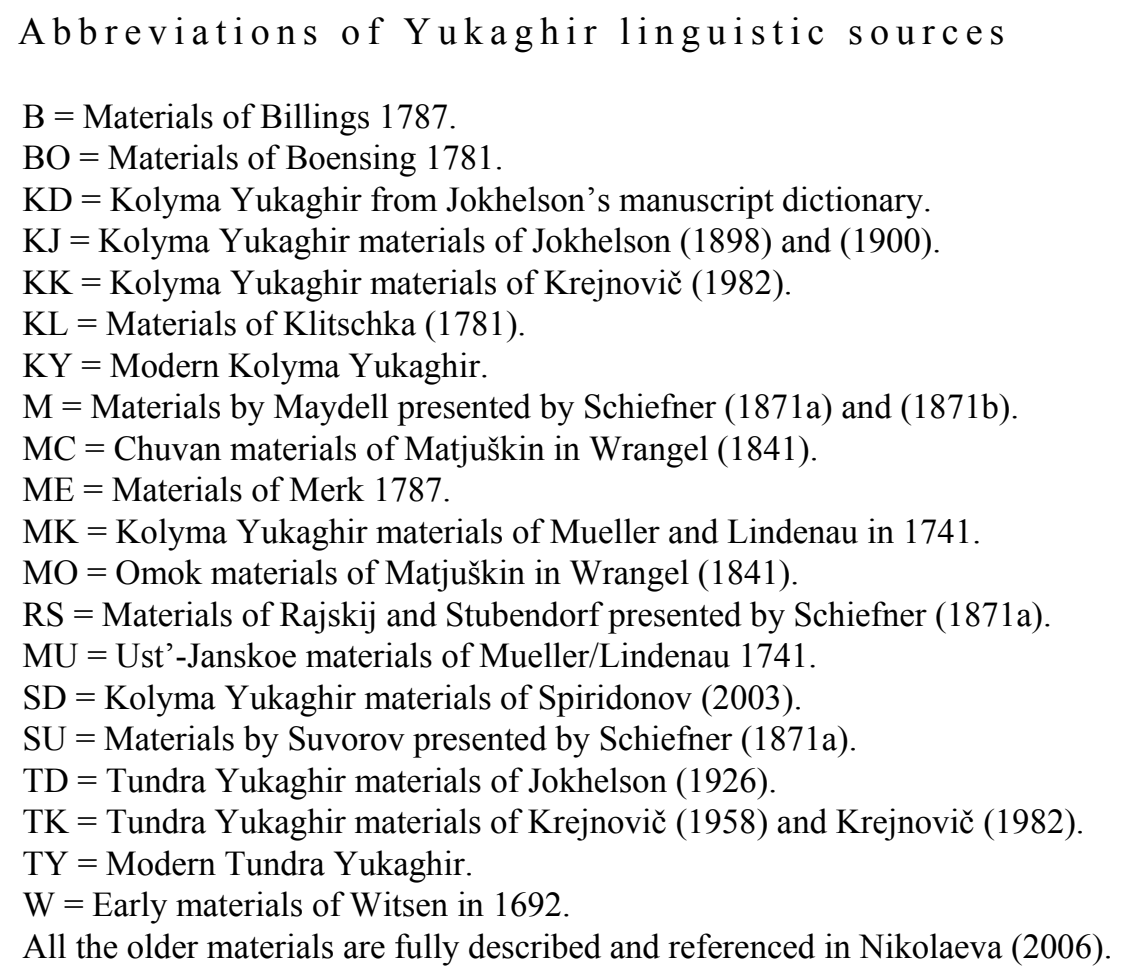

\section{References}

Aikio 2014 - Aikio A. Studies in Uralic etymology III: Mari etymologies // Linguistica Uralica. 2014, L, 2. P. 81—93.

Angere 1957 - Angere J. Jukagirisch-Deutsches Wörterbuch. Stockholm: Almqvist \& Wiksell, Wiesbaden: Otto Harrassowitz, 1957.

Aptullah 1934 - Aptullah B. Ibnü-Mühenna lûgati \{Mongolian glosses in Ibnü-Mühenna’s dictionary\}. Istanbul, 1934.

Atlasova 2007 - Атласова Э. С. Словарь юкагирско-русский и русско-юкагирский (тундренный диалект) около 3500 слов. СПб., 2007. \{Atlasova Ė.S. Yukaghir-Russian and Russian-Yukaghir dictionary (Tundra dialect) about 3500 words. Saint Petersburg, 2007.\}

Doerfer 1985 - Doerfer G. Mongolo-Tungusica. Wiesbaden: Harrassowitz, 1985.

Doerfer 2004 - Doerfer G. Etymologisch-Ethnologisches Wörterbuch tungusischer Dialekte (vornehmlich der Mandschurei). Hildesheim-Zürich-New York: Georg Olms Verlag, 2004.

EDAL - Starostin S., Dybo A., Mudrak O. An etymological dictionary of Altaic languages. Leiden: Brill, 2003.

EDT - Clauson G., Sir. Etymological dictionary of pre-thirteenth-century Turkish. Oxford: Clarendon, 1972.

Fedotov 1996 - Федотов М. Р. Этимологический словарь чувашского языка. Чебоксары, 1996. \{Fedotov M. R. An etymological dictionary of the Chuvash language. Cheboksary, 1996.\} 
Haenisch 1939 - Haenisch E. Wörterbuch zu Mangholun Niuča Tobčaan (Yüanchьao pishi), Geheime Geshichte der Mongolen. Leipzig, 1939.

Jokhelson 1898 - Иохельсон В.И. Образцы материалов по изучению юкагирского языка и фольклора, собранные в Якутской экспедиции // Известия Академии наук. 1898, сентябрь.Т. IX. № 2. C. 151-177. \{Jokhelson $W$. Samples of materials for studying Yukaghir language and folklore collected during the Yakut expedition // Bulletin of the Russian Academy of Sciences. 1898, September. Vol. 9, pt. 2. P. 151-177.\}

Jokhelson 1900 - Иохельсон В.И. Материалы по изучению юкагирского языка и фольклора, собранные в Колымском округе I. Образцы народной словесности юкагиров (тексты с переводом) // Тр. Якутской экспедиции, снаряженной на средства И. М. Сибирякова. Т. ІХ. Ч. 3. СПб.: ИАН, 1900. С. XV, 240. \{Jokhelson W. Materials on the Yukaghir language and Folklore, gathered in the Kolyma okrug I. Samples of Yukaghir folklore (texts witn translation) // Proceedings of the Yakut expedition, equipped with funds from I. M. Sibiryakov. Vol. IX. Pt 3. Saint Petersburg: Bulletin of the Russian Academy of Sciences, 1900. P. XV, 240.\}

Jokhelson 1926 - Jokhelson W. The Yukaghir and Yukaghirized Tungus // Jesup North Pacific expedition. Publications. Vol. IX. American Museum of Natural History. Memoir. Vol. XIII. Leiden: E.J. Brill; New York: G.E. Stechert \& Co., 1926. Pt. 3. P. 343-469.

JRS - Слепцов П. А. Якутско-русский словарь. М., 1972. \{Sleptsov P. A. Yakut-Russian dictionary. Moscow, 1972.\}

Kozin 1941 - Козин C. А. Сокровенное сказание. Москва - Ленинград, 1941. \{Kozin S. A. The Secret History. Moscow — Leningrad, 1941.\}

Krejnovič 1958 - Крейнович E. A. Юкагирский язык. Москва - Ленинград, 1958. \{Krejnovič E. A. The Yukaghir language. Moscow — Leningrad, 1958.\}

Krejnovič 1982 - Крейнович E. A. Исследования и материалы по юкагирскому языку. Ленинград, 1982. \{Krejnovič E. A. Studies and materials on the Yukaghir language. Leningrad, 1982.\}

Kurilov 1990 - Курилов Г. Н. Юкагирско-русский словарь. Якутск, 1990. \{Kurilov G. N. Yukaghir-Russian dictionary. Jakutsk, 1990.\}

Kurilov 2001 - Курилов Г. Н. Юкагирско-русский словарь. Новосибирск, 2001. \{Kurilov G. N. Yukaghir-Russian dictionary. Novosibirsk, 2001.\}

Lessing 1960 - Lessing F. D. Mongolian-English dictionary. Los Angeles \& Berkeley: University of California Press, 1960.

Maslova 2003 - Maslova E. A Grammar of Kolyma Yukaghir. Bossong, G., Comrie, B. \& Dryer, M. (eds.). Mouton Grammar Library 27. Berlin-New York: Mouton de Gruyter, 2003.

MGCD - Zhu S. 语族语言词典蒙古 (Měnggǔ yǔzú yǔyán cìdián) \{Dictionary of the Language(s) of the Mongolian Nationality\}. Xining: Qinghai renmin chubanshe \{Qinghai People’s Press\}, 1990.

Nikolaev 2015 - Nikolaev S. L. Toward the reconstruction of Proto-Algonquian-Wakashan. Pt. 1: Proof of the Algonquian-Wakashan relationship // Journal of Language Relationship. 2015, 13/1. P. 23-61.

Nikolaeva 2006 - Nikolaeva I. A historical dictionary of Yukaghir. (Trends in Linguistics Documentation 25.) Berlin \& New York: Mouton de Gruyter, 2006.

Nikolaeva, Shalugin 2002 - Николаева И. A., Шалугин В. Г. Юкагирско-русский словарь. СПб., 2002. \{Nikolaeva I. A., Shalugin V. G. Yukaghir-Russian dictionary. Saint Petersburg, 2002.\}

Nugteren 2011 - Nugteren, H. Mongolic phonology and the Qinghai-Gansu languages. Utrecht: LOT, 2011.

Nyikolajeva 2000 - Nyikolajeva I. Chrestomathia Jucagirica (Urálisztikai Tanulmányok 10). Budapest, 2000.

Piispanen 2013 — Piispanen P. S. Further lexical borrowings from (Pre-)Yakut into the Yukaghiric languages // Turkic Languages. 2013, 17(1/2). P. 115-139.

Piispanen 2015 - Piispanen P. S. Extensive borrowing of reindeer terminology in north-eastern Siberia // Turkic Languages. 2015, 19(1/2). P. 240-258.

Piispanen 2016 — Piispanen P.S. Folklore borrowings in north-eastern Siberia // Turkic Languages. $2016,20$. P. $257-272$.

Piispanen 2018 - Piispanen P. S. Additional Turkic and Tungusic Borrowings into Yukaghir// Turkic Languages. 2018, 22. P. 108-138.

Piispanen 2019a - Piispanen P. S. Additional Turkic and Tungusic Borrowings into Yukaghir II // Journal of Old Turkic Studies (JOTS). 2019, 3(1). P. 54-82.

Piispanen 2019b - Piispanen P. S. Additional Turkic and Tungusic Borrowings into Yukaghir III // Journal of Old Turkic Studies (JOTS). 2019, 3(2). P. 321-371.

Piispanen 2020a - Piispanen P. S. Additional Turkic and Tungusic Borrowings into Yukaghir IV // Journal of Old Turkic Studies (JOTS). 2020, 4(1). P. 152-187.

Piispanen 2020b - Piispanen P. S. Additional Turkic and Tungusic Borrowings into Yukaghir V, forthcoming.

Piispanen 2020c - Piispanen P. S. Yup'ik Eskimo loan etymologies for the Yukaghir languages and dialects, forthcoming.

Poppe 1966 - Poppe N. On some ancient Mongolian loanwords in Tungus // Central Asiatic Journal. 1966, 11(3). P. $187-198$. 
Rozycki 1994 - Rozycki W. Mongol elements in Manchu. Indiana, Bloomington: Research Institute for Inner Asian Studies, 1994.

Schiefner 1871a - Schiefner A. Beiträge zur Kenntnis der jukagirischen Sprache // Bulletin de l'Académie Impériale des Sciences. 1871a, 3/16. S. 373-399.

Schiefner 1871b - Schiefner A. Über Baron Gerhard von Maydell's jukagirische Sprachproben // Mélanges Asiatiques. 1871b, 6/5. P. 600-626.

Spiridonov 1997 - Спиридонов В. К. Школьный русско-юкагирский словарь. Якутск, 1997. \{Spiridonov V. K. School Russian-Yukaghir dictionary. Jakutsk, 1997.\}

Spiridonov 2003 - Спиридонов Н. И. Юкагирско-русский словарь и эвенско-русский словарь. Якутск, 2003. \{Spiridonov N. I. Jukaghir-Russian dictionary and Even-Russian dictionary. Jakutsk, 2003.\}

TMS - Цинциус В. И. Сравнительный словарь тунгусо-маньчжурских языков 1. Ленинград, 1975. \{Tsintsius V. I. Comparative dictionary of the Tungus-Manchu languages 1. Leningrad, 1975.\}

UEW — Rédei K. Uralisches etymologisches Wörterbuch. Budapest: Akadémiai Kiadó, 1988-1991.

Vasilevič 1958 - Василевич Г. М. Эвенкийско-русский словарь. М., 1958. \{Vasilevič G. M. Ewenki-Russian dictionary. Moscow, 1958.\}

VEWT - Räsanen M. Versuch eines etymologisches Wörterbuchs der Türksprachen. Helsinki: Suomalais-Ugrilainen Seura, 1969.

Wrangel 1841 - Врангель Ф.П. Путешествие по северным берегам Сибири и по Ледовитому морю, совершенное в 1820, 1821, 1822, 1823 и 1824 годах экспедицию, состоявшею под начальством флота лейтенанта Фердинанда фон Врангеля. Т. $1-2$. СПб., 1841. \{Wrangel F. von. A voyage along the northern coast of Siberia and the Arctic Sea made in 1821, 1822, 1823 and 1824 under the expedition of lieutenant Ferdinand von Wrangel. Vols. 1-2. Saint Petersburg, 1841.\} 